\title{
Use of liners made of concrete on quartz aggregates and polyurethane composition to reduce vibration, noise and improve the stability of tramway track
}

\author{
Olena Palant, Dmytro Plugin ", Andrii Plugin, Alexey Lobiak, and Oleksii Pluhin \\ Ukrainian State University of Railway Transport, Feuerbach sq. 7, 61050 Kharkiv, Ukraine
}

\begin{abstract}
The theoretical basis of reduction of thermal deformations of the ballastless continuous welded track has been developed. The design of the track with integrated rails has been improved by using a special concrete liner of optimal composition with quartz fillers and aggregates and two-component polyurethane. The method of calculating the concrete composition with optimal strength and coefficient of linear thermal expansion together with optimal structural characteristics, To reduce the temperature stresses in the rails, liners should be made of concrete with quartz fillers and aggregates which provide a reduction of the coefficient of linear thermal expansion $\alpha_{L}$ to $1.1 \times 10^{-6} \mathrm{~K}^{-1}$. The analysis of the stressstrain state of the rails during heating, performed using the finite element method, has shown that the liners made of concrete with quartz aggregates decrease by $10-32 \%$ the temperature stresses in rails. The composition of concrete for liners with the compressive strength of above $60 \mathrm{MPa}$ has been substantiated and the polyurethane composition has been selected for insulation of rails from the channel wall with adhesion to concrete of $0.7 \mathrm{MPa}$ in a dry state, $0.43 \mathrm{MPa}$ in a water-saturated state, and adhesion to steel of $1.2 \mathrm{MPa}$.
\end{abstract}

\section{Introduction}

Electric tramway is an environmentally friendly, affordable and convenient type of public transport. However, it also has certain shortcomings, such as hindering movement of other modes of transport, generating noise and vibration, as well as permanent leakage currents from rails which can cause electric corrosion of nearby metal and reinforced concrete structures and pipelines. The use of continuous welded tramway track with insulated rails on the ballastless reinforced concrete base integrated into the roadway cannot completely eliminate the above shortcomings; therefore the rationale for measures to reduce vibration, noise, leakage currents and temperature stresses in such tracks is currently relevant.

\footnotetext{
* Corresponding author: plugin.da@gmail.com
} 
The purpose of the study is theoretical and experimental rationale of measures aimed at reduction of vibration, noise, temperature stresses and leakage currents in tramway tracks with insulated rails on the ballastless reinforced concrete track.

\section{Analysis of design features and operating conditions of tramways with insulated rails}

The tramway with isolated rails on a ballastless reinforced concrete base integrated into the roadway is becoming increasingly common everywhere in the world [1]. Rails should be installed in railway channels to make sure railheads are on level with the road surface. The rails are mounted on continuous polyurethane rail pads and attached to the concrete walls of the channels and, at the same time, are isolated from them by polyurethane seal. A significant reduction in noise and vibration can thus be achieved.

The disadvantage of this design is high consumption of expensive polyurethane sealer, plastic pipes are laid in the gap between the rail and the channel wall or concrete liners are glued to the rail web to save the sealer.

A characteristic feature of the design being analyzed is the absence of any mechanical fastening of rails to the base. The rails are held in the channel only with the seal which actually acts as a wedge for the rail, and vertical and longitudinal movement is prevented mainly by its adhesion to the concrete surface of the channel walls. As a result, the continuous welded tramway of such design can be unstable, especially when block rails are used, which is evidenced by cases of distortion of the track from temperature stresses [2]. Leakage currents from tramway tracks are known to cause electric corrosion of nearby metal and reinforced concrete structures and pipelines. However, the assumed high protective properties of the analyzed design are still not investigated.

When trams are moving, derailments caused by the wear and tear of the track and rolling stock, speed infringement due to the human factor and traffic accidents occur periodically [2]. Additional factors contributing to such derailments may include electric forces caused by the accumulation of excess electric charges of both natural and anthropogenic origin on the tramway and rolling stock [3, 4].

The tramway design with insulated rails on the ballastless reinforced concrete base has been improved with reference to the tramway in Kharkiv (Ukraine) (Fig. 1) [5].

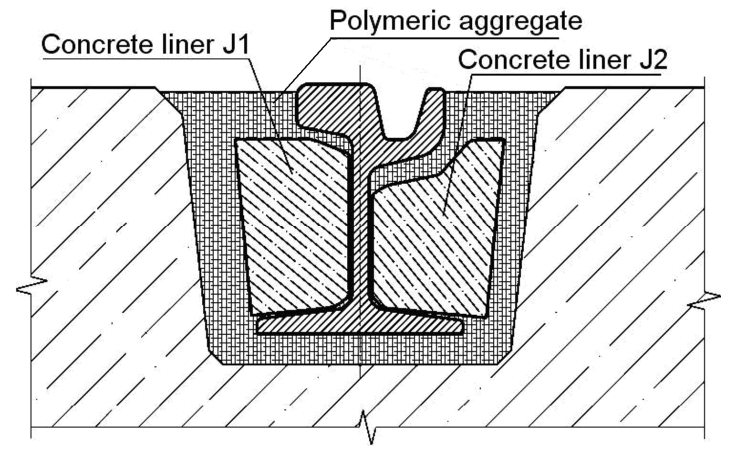

Fig. 1. A rail isolated with a polyurethane composition with concrete liners in the reinforced concrete slab channel.

Concrete liners which are rigidly glued to the rail web only help save polyurethane seal, but also damp vibrations of rails. 


\section{Main study materials}

Prof. A.N. Plugin suggested to use liners (Fig. 1), in particular to reduce the temperature stresses in rails. For this purpose, the minimum possible coefficient of linear thermal expansion $\alpha_{L}$ should be provided for liners, which would be much lower than that of steel. Since the most volume of concrete is filled with aggregates, aggregates with minimum values of $\alpha_{L}$ should be used.

Table 1 contains values of the coefficients of linear thermal expansion $\alpha_{L}$ of the materials of the tramway track shown in Fig. 1

Table 1. Coefficients of linear thermal expansion $\alpha_{L}$ of the materials of tramway track [7].

\begin{tabular}{|c|c|}
\hline Material & $\boldsymbol{\alpha}_{\boldsymbol{L}}, \mathbf{K}^{-\mathbf{1}}$ \\
\hline Steel & $13 \times 10^{-6}$ \\
\hline Heavy concrete & $10 \times 10^{-6}$ \\
\hline Granite & $7.9 \times 10^{-6}$ \\
\hline Quartz & $(0.77-1.4) \times 10^{-6}$ \\
\hline Polyurethane & $57.6 \times 10^{-6}$ \\
\hline
\end{tabular}

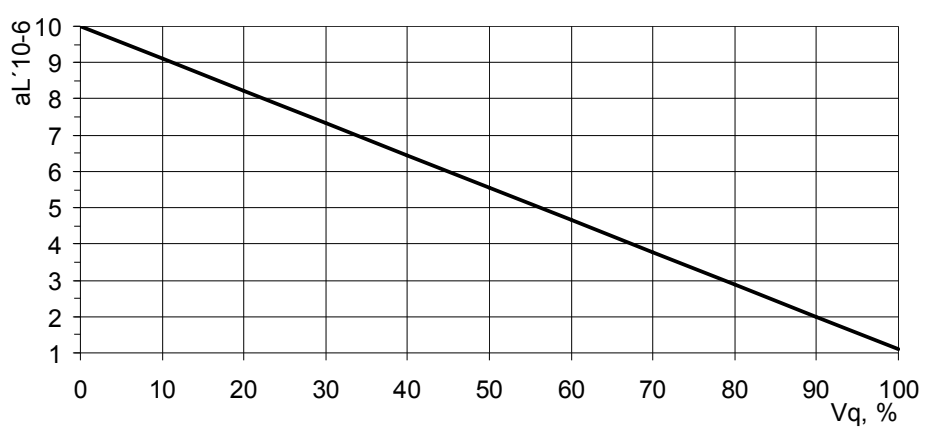

Fig. 2. Dependence of the coefficient of linear thermal expansion of concrete $\alpha_{L}$ on the volume content of quartz aggregates and fillers $V_{q}$ in it.

According to Table 1, quartz is characterized with minimum values $\alpha_{L}$ - in average, $1.1 \mathrm{~K}^{-1}$. Replacement of crushed granite in heavy concrete with crushed quarts, and part of cement $(\mathrm{C})$ with quartz filler $(\mathrm{F})$ will allow decreasing $\alpha_{L}$ by an order of magnitude - from $10 \times 10^{-6} \mathrm{~K}^{-1}$ to about $1.1 \times 10^{-6} \mathrm{~K}^{-1}$. Supposing $\alpha_{L}$ of cement rock is near to $\alpha_{L}$ of heavy concrete, and $\alpha_{L}$ depends inversely on the volume content of quartz (crushed stone (CS), sand (S) and filler) $V_{q}$, this dependence will be written as shown in Fig. 2.

\subsection{Analysis of the stress-strain state of the rails during heating}

The stress-strain state of rails during heating has been analyzed to verify the assumption that the temperature stresses in rails decrease after concrete liners with a lower value of $\alpha_{L}$ are glued onto it. The stress-strain state of such rails has been analyzed by the finite element method using Lira software complex. Isofields of temperature stresses in the rail without liners and with liners from a temperature increase are presented in Fig. 3, 4, the results of the analysis are given in Table 2. 


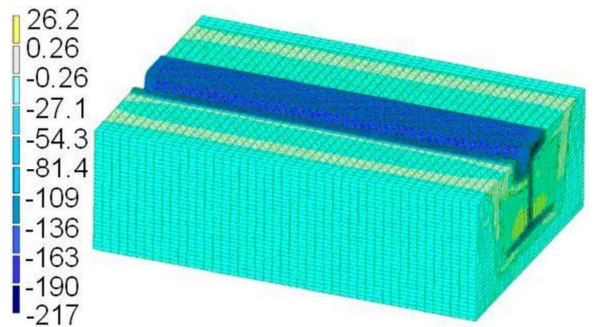

a)

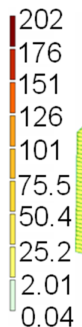

2.01
0.04

.04

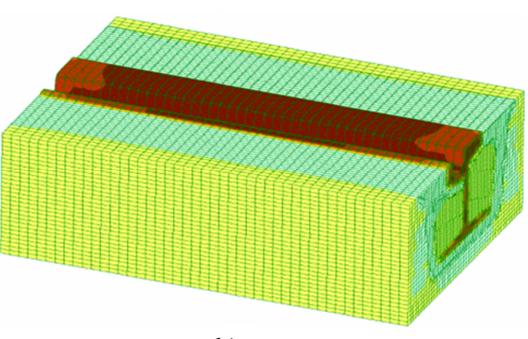

b)

Fig. 3. Stress isofields in the rail with liners when the temperature rises by $80 \mathrm{~K}$ : a - main; $\mathrm{b}$ - equivalent.

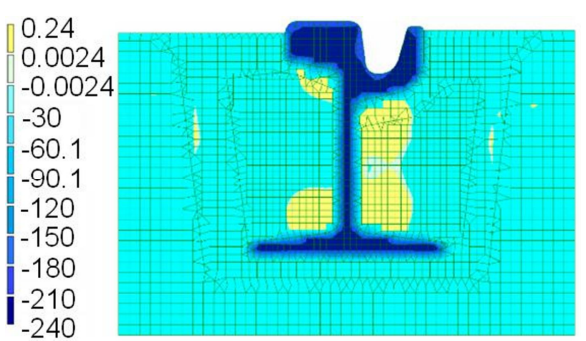

a)

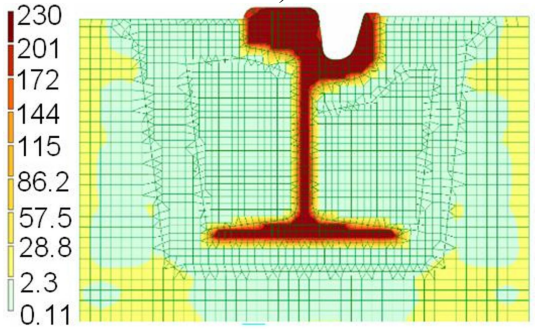

c)

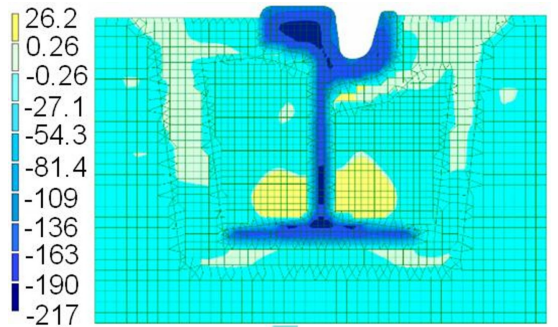

b)

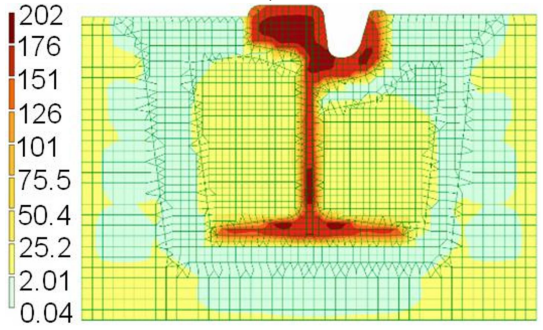

d)

Fig. 4. Stress isofields when the temperature rises by $80 \mathrm{~K}: \mathrm{a}, \mathrm{b}$ - main; $\mathrm{c}, \mathrm{d}$ - equivalent; $\mathrm{a}, \mathrm{c}-$ in the rail without liner; $\mathrm{c}, \mathrm{d}-$ in the rail with liners.

Table 2. Results of the analysis of the stress-strain state of the rail without liners and with liners during heating.

\begin{tabular}{|c|c|c|c|c|c|}
\hline \multirow{2}{*}{$\begin{array}{l}\text { Heating vs. the } \\
\text { initial temperature } \\
\text { (stress-free temp.) }\end{array}$} & \multirow[b]{2}{*}{ Stresses } & \multirow{2}{*}{$\begin{array}{l}\text { Rail } \\
\text { Section } \\
\text { area }\end{array}$} & \multicolumn{2}{|c|}{ Stresses in the rail, MPa } & \multirow{2}{*}{$\begin{array}{l}\text { Effect of the } \\
\text { liners - decrease } \\
\text { in stress, \% }\end{array}$} \\
\hline & & & $\begin{array}{l}\text { without } \\
\text { liners }\end{array}$ & with liners & \\
\hline \multirow{4}{*}{ by $20 \mathrm{~K}$} & main & web & \multirow{3}{*}{57.4} & $40.7-52.5$ & $12-32$ \\
\hline & compressive & head & & $42.0-54.4$ & $10-30$ \\
\hline & N3 & $\max$ & & 54.4 & 10 \\
\hline & equivalent & & 60.1 & 50.4 & 12 \\
\hline \multirow{4}{*}{ by $80 \mathrm{~K}$} & main & web & \multirow{3}{*}{240} & $163-195$ & $18-32$ \\
\hline & compressive & head & & $175-217$ & $10-27$ \\
\hline & N3 & $\max$ & & 217 & 10 \\
\hline & equivalent & & 230 & 202 & 12 \\
\hline
\end{tabular}

Characteristics of the finite element model are as follows:

- length: $1 \mathrm{~m}$, along the ends of the binding rail (along the axis) with finite rigidity being an order of magnitude greater than for all other bonds (maximum displacement of end butts during heating by $80 \mathrm{~K}$ is $0.02 \mathrm{~mm}$ ); 
- in the transverse direction along the outer boundary of the model (slab), bonds of finite stiffness are established ensuring the displacement of the boundaries at $80 \mathrm{~K}$ not more than by $0.028 \mathrm{~mm}$ in horizontal directions and not more than by $0.003 \mathrm{~mm}$ vertically downwards;

- slab concrete $-\mathrm{C} 25 / 30$, liner concrete $-\mathrm{C} 32 / 40, \alpha_{L}$ of liners $-1.1 \times 10^{-6} \mathrm{~K}^{-1}$;

- rail heating is uniform heightwise, while along other sections - according to the stress diagram from $100 \%$ (in the point of contact with the rail) to $40 \%$ of the rail temperature from top to bottom, liners - from $90 \%$ (in the point of contact with the rail) to $50 \%$ of the rail temperature.

Thus, the analysis of the stress-strain state of the rail during heating shows that liners made of concrete on quartz aggregates reduce by $10-32 \%$ temperature stresses in rails which cause distortion of the track.

\subsection{Rationale of the concrete composition of liners}

The liner material is concrete of optimum composition [6], with the maximum strength and low deformability. The properties of such concrete determine its known optimal structural characteristics, such as the coefficients of separation of grains of crushed stone $\alpha_{O P T}$, sand $\mu_{O P T},(\mathrm{~W} / \mathrm{C})_{\mathrm{OPT}}$ and the optimum amount of the superplasticizer (SP) $)_{\mathrm{OPT}}$. Optimum coefficients of separation of grains of crushed stone $\alpha_{O P T}$ and sand $\mu_{O P T}$ are determined by expressions [8]:

$$
\alpha_{O P T}=2.1 \cdot\left(1+\frac{d_{S}}{d_{C S}}\right)^{3}-1.1, \quad \mu_{O P T}=2.1 \cdot\left(1+\frac{d_{C}}{d_{S}}\right)^{3}-1.1
$$

where $d_{C S}, d_{S}$ and $d_{C}$ - average size of crushed stone and sand grains and cement particles, $\mathrm{mm}$.

Crushed stone with fineness $5-10 \mathrm{~mm}$ and average grain size $d_{C S} 7.5 \mathrm{~mm}$ was used. The average sand grain size $d_{S}$ can be calculated using the known ratios: for sand with fineness modulus $\mathrm{FM}=1, d_{S}=0.23 \mathrm{~mm} ; \mathrm{FM}=2.5, d_{S}=0.49 \mathrm{~mm}$.

Based on the above, an approximate diagram was plotted, Fig. 5, according to which for $\mathrm{FM}=1.9 d_{S}=0.37 \mathrm{~mm}$.

If we substitute these values to (1), we will get: $\alpha_{O P T}=2.1 \times(1+0.37 / 7.5)^{3}-1.1=1.32$.

Experimental verification of the value of $\mu_{O P T}$ has been performed by making concrete samples using formulations with different values of $\mu$, Table 3 , and testing them for compressive strength, Table 4.

This value has been confirmed experimentally.

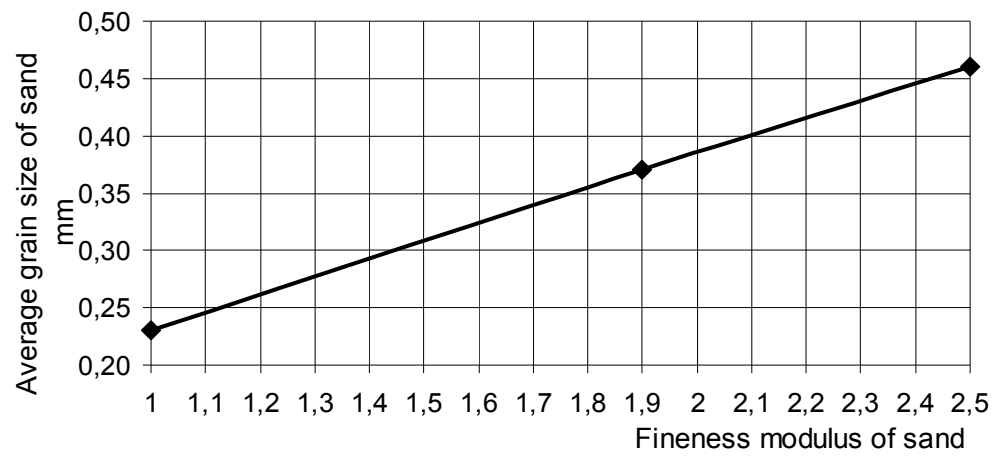

Fig. 5. Approximate dependence of the average sand grain size on its fineness modulus. 
Table 3. Experimental concrete compositions and structural coefficients for compressive strength testing of concrete.

\begin{tabular}{|c|c|c|c|c|c|c|c|}
\hline Composition No. & S & CS & $\mathbf{C}$ & $\mathbf{W}$ & $\mathbf{C} / \mathbf{W}$ & $\boldsymbol{\alpha}$ & $\boldsymbol{\mu}$ \\
\hline 1 & 1.000 & 900 & 350 & 182 & 1.75 & 2.56 & 1.09 \\
\hline 2 & 800 & 1.100 & 350 & 175 & 1.85 & 1.83 & 1.33 \\
\hline 3 & 600 & 1.300 & 350 & 167 & 2.00 & 1.32 & 1.73 \\
\hline 4 & 400 & 1.500 & 350 & 158 & 2.17 & 0.95 & 2.51 \\
\hline
\end{tabular}

Table 4. Compressive strength of concretes, MPa.

\begin{tabular}{|c|c|c|c|c|c|c|}
\hline \multirow{2}{*}{$\begin{array}{c}\text { Composition } \\
\text { No. }\end{array}$} & \multicolumn{3}{|c|}{ without additive } & \multicolumn{3}{c|}{ with additive Sika Plast 2508 } \\
\cline { 2 - 7 } & 3 days & $\mathbf{7 ~ d a y s}$ & $\mathbf{2 8}$ days & 3 days & 7 days & 28 days \\
\hline 1 & 23.2 & 30.0 & 40.3 & 29.3 & 38.2 & 49.4 \\
\hline 2 & 38.1 & 48.0 & 54.0 & 42.2 & 51.3 & 62.1 \\
\hline 3 & 37.4 & 47.5 & 53.8 & 47.3 & 59.4 & 69.0 \\
\hline 4 & 33.8 & 42.1 & 49.4 & 39.0 & 49.7 & 60.3 \\
\hline
\end{tabular}

In addition, in a concrete mix with a superplasticizer additive, unlike the plain concrete, the like-charged cement particles and sand grains bounce off each other, and the mixture turns into a suspension. Setting of such a suspension begins with the formation of ettringite, which grows with its long side along the normal from the surfaces, similarly to the growth of ettringite in the voids (large air-bubble cavities), Fig. 6.

Judging by the scale of this picture, the length of the ettringite blocks is about $18-20 \mu \mathrm{m}$, in average $19 \mu \mathrm{m}$. Therefore, in accordance with (1) $\mu_{O P T}=2.1 \times(1+2 \times 0.019 / 0.37)^{3}-1.1=1.72$, which is also close to the experimental value $\mu_{O P T}=1.74$, Fig. 7 .

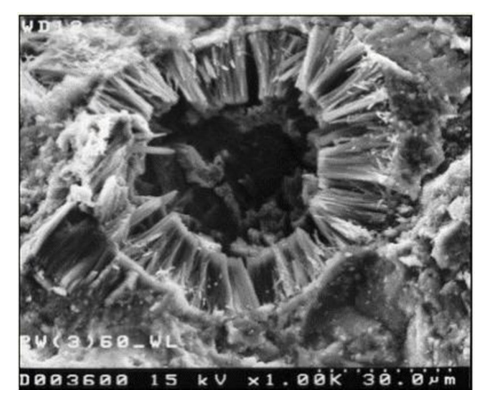

Fig. 6. Ettringite in air voids [9].

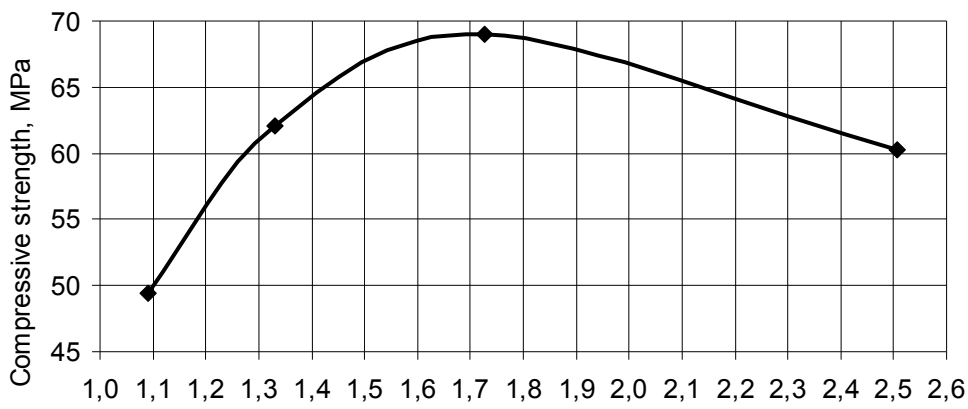

Coefficient of separation of sand grains, $\mu$

Fig. 7. Dependence of the compressive strength of concrete with the addition of a superplasticizer on the coefficient of separation of sand grains $\mu$ and $\mathrm{C} / \mathrm{W}$. 
Water consumption in the concrete with a superplasticizer additive, according to the experimental data, is $160 \mathrm{~kg} / \mathrm{m}^{3}$ so that a placeable concrete mixture is obtained.

The specific feature of the use of ground quartz as a filler is that its average particle size is $50 \mu \mathrm{m}$, similarly to that of cement particles. Thus a uniform, homogeneous mixture of grains can be obtained.

Consumption of crushed stone, sand and water of the liner concrete is determined by the known formulas from [8]. They were, for $1 \mathrm{~m}^{3}: \mathrm{CS}=1210 \mathrm{~kg}, \mathrm{~S}=556 \mathrm{~kg}, \mathrm{~W}=1671$.

According to [10], plastic consistency consolidated by vibration SPTsVS is achieved when $\mathrm{W} / \mathrm{C}=0.32$. Accordingly, $\mathrm{C}=167 / 0.32=520 \mathrm{~kg} / \mathrm{m}^{3}$.

Absolute volume of the calculated cement is:

$$
\mathrm{V}_{\mathrm{CP}}=\frac{\mathrm{C}}{\rho_{\mathrm{C}}}=\frac{520}{3.1}=168 \quad\left(1 / \mathrm{m}^{3}\right)
$$

Let us assume that absolute volumes of cement and aggregate in the mixture are identical, $0.084 \mathrm{~m}^{3}$ each. Accordingly, their consumptions will be: $\mathrm{C}=0.084 \times 3100=260\left(\mathrm{~kg} / \mathrm{m}^{3}\right) ; \quad \mathrm{F}=0.084 \times 2.650=223\left(\mathrm{~kg} / \mathrm{m}^{3}\right)$. Amount of the superplasticizer naphthalene-formaldehyde type additive $\mathrm{SP}=0.32 \times 260 / 100=0.83 \mathrm{~kg}$.

The final composition of the concrete of a special rail liner is as follows:

$$
\mathrm{CS}=1210 \mathrm{~kg} ; \mathrm{S}=556 \mathrm{~kg} ; \mathrm{C}=260 \mathrm{~kg} ; \mathrm{F}=223 \mathrm{~kg} ; \mathrm{W}=167 \mathrm{l} ; \mathrm{SP}=0.83 \mathrm{~kg} .
$$

The coefficient of separation of the cement mixture and ground quartz $\mu_{O P T \cdot F}$ has its specific characteristics. A mixture of cement and ground quartz with identical particle sizes $(50 \mu \mathrm{m})$ is placed inside the voids of a mixture of crushed stone and sand. In the presence of a superplasticizer additive, all particles of the mixture of cement and ground quartz have a negative charge, and thus the mixture is a dispersion system. When cement hydration begins, ettringite crystal hydrates are its first products, with the transverse size of $0.3-0.7 \mu \mathrm{m}[11]$ and an average size of $0.5 \mu \mathrm{m}$. When curing begins, they grow from the surface of cement and ground quartz particles as if on the substrate, forming electroheterogeneous contacts, Fig. 8.

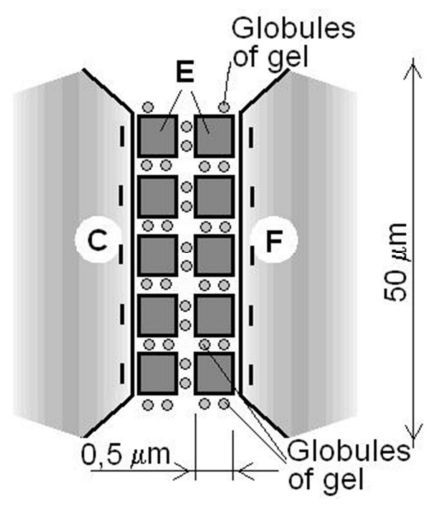

Fig. 8. Electric heterogeneous contact between cement (C) and ground quartz (F) particles via ettringite particles (E).

In accordance with the scheme in Fig. 8, the optimum coefficient of separation of cement particles and ground quartz by the products of cement hydration is $\mu_{C+F}=2.1 \times(1+2 \times 0.5 / 50)^{3}-1.1=1.13$. 


\subsection{Experimental rationale of a polymer composition for rail insulation in the channel}

A rail with liners is built into the slab channel, in which the lateral sides extend upward, Fig. 1. This reduces the adhesion of the polyurethane sealing material to the concrete channel, which can draw the rail stack out of it. To prevent this, according to the calculation, adhesion strength of the sealing mass to the steel rail and concrete should be at least $0.7 \mathrm{MPa}$. The corresponding laboratory tests of two-component polyurethanes Edilon Corkelast ${ }^{\circledR}$ (edilon)(sedra, Netherlands), Icosit KC 340/45 F (Sika, Switzerland-Poland) and new composition "X" (Kharkiv, Ukraine) for adhesion to steel and concrete have been conducted.

The results of the adhesion tests of these polyurethane compositions are summarized in Table 5.

Table 5. Adhesive strength to the surface of steel and concrete of polymeric compositions.

\begin{tabular}{|l|c|c|c|}
\hline \multirow{2}{*}{ Polyurethane composition } & \multicolumn{3}{|c|}{ Adhesive strength, MPa } \\
\cline { 2 - 4 } & \multirow{2}{*}{ To steel } & \multicolumn{2}{|c|}{ To concrete } \\
\cline { 3 - 4 } & & dry & water-saturated \\
\hline Edilon Corkelast & $>0.8$ & $>0.8$ & - \\
\hline Icosit C340/45F & 0.88 & 0.61 & 0.24 \\
\hline Composition "X" & 1.20 & 0.70 & 0.43 \\
\hline
\end{tabular}

By the results of these studies, it has been accepted that all investigated polymers can be used as a two-component polyurethane to seal in rails into a tramway slab: Edilon Corkelast (edilon)(sedra, Netherlands), Icosit KC 340/45 F (Sika, Switzerland-Poland) and Composition "X" (Kharkiv, Ukraine). However, the last two in the Ukrainian market are much more economic, than Edilon Corkelast ${ }^{\circledR}$.

\section{Conclusions}

1. The design of the tramway track with insulated rails on the ballastless reinforced concrete base, in which the concrete liners that are rigidly glued to the rail web not only help save polyurethane seal, but also damp vibrations of rails and reduce thermal stresses in rails, has been improved.

2. To reduce the temperature stresses in rails, the liners should be made of concrete on quartz aggregates and fillers to ensure a reduction in the coefficient of linear thermal expansion $\alpha_{L}$ to $1.1 \times 10^{-6} \mathrm{~K}^{-1}$. The analysis of the stress-strain state of rails during heating conducted using the finite element method has shown that the liners made of concrete on quartz aggregates reduce by $10-32 \%$ the temperature stresses in rails which cause distortion of the track.

3. The composition of liner concrete with compressive strength over $60 \mathrm{MPa}$ has been substantiated and the polyurethane composition for insulation of rails from the wall of channels with adhesion to dry concrete $0.7 \mathrm{MPa}$, to water-saturated concrete $0.43 \mathrm{MPa}$, and to steel 1.2 MPa has been selected.

\section{References}

1. T. Shuba, V. Chystiak, V Perestiuk, O. Yeliakina, O.A. Zabiiaka, A.A. Plugin, Collected scientific works Ukrainian State Academy of Railway Transport, 122, 201-221 (2011) 
2. Velkoplošné panely BKV // Prazske tramvaje. Available at: http://www.prazsketramvaje.cz/view.php?cisloclanku=2006041296

3. O.A. Zabiiaka, Collected scientific works Ukrainian State Academy of Railway Transport, 155, 98-102 (2015)

4. A.M. Plugin, O. Pluhin, O. Palant, O. Konev, A. Nykytynskyj, Matec Web of Conference, 116, 01011 (2017)

5. O.V. Palant, O.M. Savchenko, D.A. Plugin, A.A. Plugin, Collected scientific works Prydniprovska State Academy of Civil Engineering and Architecture, 104, 194-199 (2018)

6. D.S. Zakharov, O.V. Palant, S.M. Tolmachiv, D.A. Plugin, P.E. Moisieeva, Collected scientific works Ukrainian State Academy of Railway Transport, 169, 64-72 (2017)

7. Temperaturnyiy koeffitsient lineynogo rasshireniya // Temperatures.ru. Available at: http://temperatures.ru/pages/temperaturnyi_koefficient lineinogo rasshireniya

8. A.N. Plugin, O.A. Kalinin, A.I. Biriukov, Yu.P. Libenko, A.I. Moiseev, Yu.M. Skorodumov, Sposob opredeleniia sostava betonnoi smesi: SU1787972[P]. (1993-01-15)

9. J. Stark, K. Bollmann, Delayed Ettringite Formation in Concrete. Available at: https://www.imxtechnologies.com/storage/app/media/uploaded-files/ettringite.pdf

10. A.M. Plugin, Art.M. Plugin, O.A. Kalinin, S.V. Miroshnichenko, A.A. Plugin, D.V. Shumyk, D.A. Plugin, A.V. Nykytynskyi, V.A. Liutyi, M.D. Kostiuk. Superplastyfikovana tsementno-vodiana suspenziia SPTsVS dlia tsementatsii hirskykh porid i budivelnykh konstruktsii: UA71208[P]. (2008-02-25)

11. A.N. Plugin, A.A. Plugin, O.A. Kalinin, S.V. Miroshnichenko, D.A. Plugin, A.S. Kaganovskiy, Al.A. Plugin, O.V. Gradoboev, Osnovyi teorii tverdeniya, prochnosti, razrusheniya i dolgovechnosti portlandtsementa, betona $i$ konstruktsiy iz nih (Naukova dumka, Kyiv, 2012) 